\title{
Economic Security Management of the Organization: System-Structural Approach
}

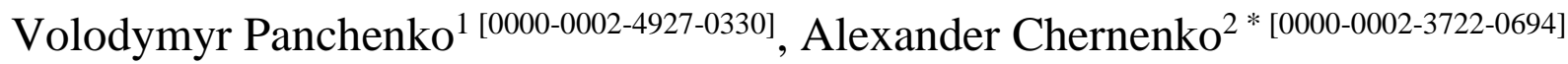 \\ ${ }^{1}$ Central Ukrainian State Pedagogical University named after V. Vynnychenko, Kropivnitsky, Ukraine \\ ${ }^{2}$ Kirovograd Institute for Human Development, Kropivnitsky, Ukraine \\ *Chernenko_O.V.fp@i.ua
}

\begin{abstract}
The article considers the features of the system-structural approach to the management of economic security of the organization. The analysis of scientific works on risk management is given. The essence of the category "economic risk management" is described, the classification of economic risks is given, the conditions and goals of crisis management are determined. The author presents a system-structural model of economic security management of the organization, developed on the basis of the concept of crisis management and proved its effectiveness. The degree of financial security of the company is an analysis of the productivity of the company's resources with the existing degree of economic and business risk. The mathematical apparatus for assessing the effectiveness of risk management is presented.
\end{abstract}

Keywords: organization management, economic security, system-structural approach, economic risk.

\section{INTRODUCTION}

The emergence of economic risk, which poses a direct threat to the business organization, causes managers to seek effective management solutions aimed at reducing possible losses. However, the difficulty of choosing the best concept for economic risk management is that existing concepts are imperfect and do not take into account a systematic approach to managing the organization. The problem of economic security was studied in the works of the following scientists: I.O. Blank, O.I. Zakharov, P.Y. Prigunov, M.I. Kamlik, M.O. Kizim, T.S. Klebanova, C.M. Scarlet. Therefore, it is important to investigate the structure of economic security of the enterprise, to determine the essence of economic security of the enterprise, classified risk management methods. It is important to look for a new concept of economic risk management to avoid possible threats and eliminate the harmful effects of the external and internal environment of the organization.

\section{RESEARCH METHODOLOGY}

The purpose of the study is to characterize the conceptual principles of managing the economic security of the organization using a system-structural approach.
The research used scientific methods: analysis (literature and management experience), system (to build a management model, to establish relationships between phenomena and processes), induction and deduction (to draw conclusions and generalizations).

\section{RESULTS OF THE RESEARCH}

1. Features of economic security management of the organization.

During the implementation of economic projects in the organization there is always an acute problem of forecasting, assessing and reducing possible risks. Any business is risky, so the main task of solving this problem is to choose an effective model of economic risk management.

Financial and economic security management is provided by a targeted impact on threats that can affect the value and market prospects of the business. The result of such influence is the neutralization and minimization of threats to financial and economic security [1, p. 108].

V. Dovgan draws important conclusions: the amount of profit depends on the degree of risk. Revolutionary business is associated with great risk. Sometimes everything is at stake. However, the return 
from such projects is incomparably higher than from the calm movement on the tracks. This is the only way to legally make a profit, because you are ahead of the competition for years and all the "cream" goes to the innovator [2].

Scientists O. Kerekesh, G. Misko, O. Malyuta established that the concept of "economic security of the enterprise" is multifaceted and is associated with the negative impact of economic risks, threats, dangers [3].

Economic risk, in our opinion, is a quantitative assessment of possible financial losses of the organization caused by the danger from the external or internal environment.

To the internal factors influencing the financial security of OS Shumilo includes: financial planning and asset management, investment policy, risk management tools in contracts, receivables, wages and salaries, control of current assets (including inventories), control over the capital structure of the enterprise, enterprise costs and others [4, p. 241].

To the general economic factors OS Shumilo refers to: the economic policy of the country, the phases of the economic cycle, the level of production in areas of specialization, turnover and others [4, p. 242].

Based on the generalization of scientific approaches to the classification of threats to financial and economic security OV Orlyk [1] offers their classification system, which allows to rank threats to the financial and economic security of the enterprise, and includes the following types:

- $\quad$ by source: external and internal threats;

- by object of encroachment: threats to financial, material, informational and labor (personnel) resources;

- by subjects of threats: threats from criminal structures, unfair competitors, contractors, own employees;

- $\quad$ if possible: real and potential threats;

- $\quad$ by the nature of the impact: direct and indirect threats;

by the nature of the causal link: explicit and implicit threats;

by the nature of occurrence: threats that arise under objective circumstances and threats that are the result of subjective decisions;

- $\quad$ by time period: current and long-term threats;

by duration of action: temporary and permanent threats;

- by the level of probability of realization: threats with high, medium and low level of realization;
- $\quad$ by the amount of probable losses: threats with permissible, critical and catastrophic amount of losses;

- by the level of severity of consequences: threats with high, significant, medium and low severity of consequences;

- $\quad$ by level of danger: threats that lead to loss of value or profit of the enterprise and can be overcome in the short, medium and long term, and threats that lead to bankruptcy of the enterprise;

- $\quad$ by form of loss: threats, the implementation of which causes direct damage, and threats, the implementation of which will lead to lost profits [1, p. 110];

- by functional components can be identified threats: budget, monetary, banking, investment, innovation, information, stock, insurance, foreign economic component of financial security of the enterprise

by the level of occurrence it is possible to distinguish the threats that arise and are manifested at the macro level, meso level and micro level [1, p. 111].

The degree of financial security of the company is an analysis of the productivity of the company's resources with the existing degree of economic and business risk [5, p. 108].

The value of risk - an indicator of the degree of risk, its value, which indicates the maximum losses that may occur during a known period of time for a certain probability [6, p. 337].

M.P. Denisenko, П.Т. Kolisnichenko, point out that the organizational and economic mechanism for improving the economic security of small and medium enterprises should be based on the use of a system of methods and organizational, regulatory, financial, informational and motivational means to influence the functional criteria of economic security, implementation of security services or transfer of functions. providing other departments of the company [7, p. 35].

2. The essence and content of the system-structural approach

Risk management (crisis management) is a business concept that involves the creation of effective actions, methods, procedures and mechanisms to identify and eliminate (or reduce) the effects of economic risks that harm the organization in order to stabilize its business and adhere to the chosen development strategy.

To date, many concepts of risk management are known: risk avoidance, retention (preservation) of risk, risk transfer, risk reduction. However, the existing concepts do not analyze the risk in the complex impact on the economic activity of the entire organization. We 
propose to consider the author's concept - a systemstructural approach.

The essence of the system-structural approach is that any organization should be considered as an open social and production system, which consists of appropriate levels of management (higher, middle, lower), elements (departments, divisions, branches) and the links between them (exchange of information, resources), and also has the purpose of activity and management mechanisms.

System-structural approach, based on three postulates:

- the organization should be considered as a system (according to the classical school of management) - a set of elements and connections;

- The organization should be considered by levels of management (structural hierarchy of power): senior (company president, board of directors), middle (branch directors, heads of departments), lower (heads of departments, heads of working groups, foremen).

- availability of management technology, vertical and horizontal coordination of work, which allows us to consider the organization as a whole.

The use of a system-structural approach in the management of economic security allows us to consider risk management at all levels of management and structural elements of the organization, which allows us to develop an effective model for any type of business.

Figure 1 presents the author's system-structural model of economic security management of the organization, developed on the basis of the concept of crisis management.

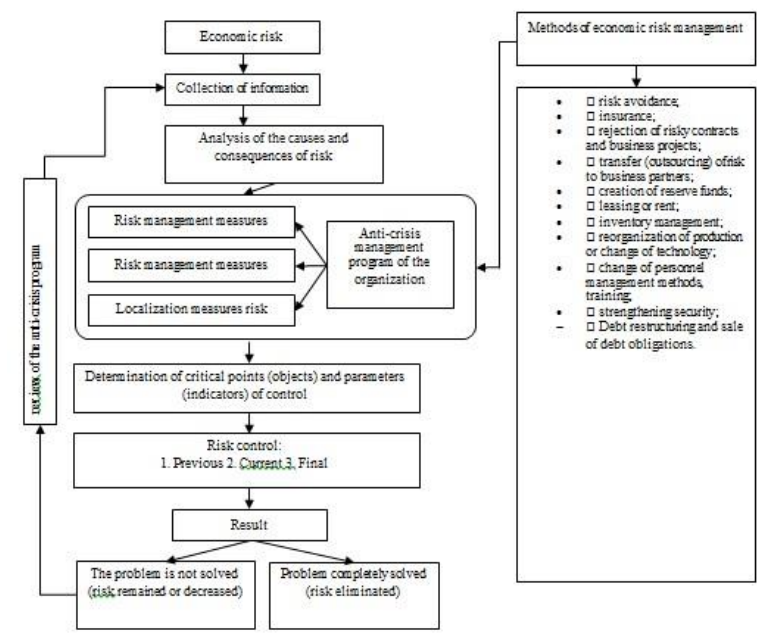

Figure 1 System-structural model of economic security management of the organization

It is established that this model (Figure 1) will be effective under the following conditions: the program of anti-crisis management of the organization (a complex of actions and methods) should be developed;

$\square$ all managers of the organization participate in the process of managing the economic security of the organization;

$\square$ information support at all levels of government.

The set of actions on risk management involves achieving the following goals:

1) economic risks must be clearly identified and classified, the level of threat perceived by all managers of the organization;

2) it is necessary to gather as much information as possible to analyze the problem, management decisions must be consistent with the strategic plans of the organization;

3) the projected final results for the elimination of risk should compensate for the costs of money, resources, time and labor.

The prerogative of this model is that it takes into account the levels of management, the relationship of all departments of the organization, which allows more competent and balanced consideration of risk from the standpoint of a systems approach.

3. Features of economic security management of the organization

The economic security management of the organization should be primarily staff-oriented. A. Schneider, J. Katzman, G. Topchishvili point to possible risks in personnel management of the organization. The risk of disruption in the work of a team of narrow-profile specialists was inevitably high, and when switching to specialists of a single profile, it decreased [8].

T. Demarko, T. Lister argue that the process of increasing productivity is associated with the risk of increasing labor turnover. It is clear that productivity cannot be increased without it. It's just that you should always take into account staff turnover when deciding to strive for increased productivity. Otherwise, you can get a "raise", which will be offset by the loss of key employees. Savings should be assessed in relation to the risk of loss of work efficiency [9].

The second feature of successful management of economic security of the organization is its interaction with consumers. It is important to be able to keep the customer in a competitive environment, emphasize A. Deligiannis, C. Argyriou, the motivation is to help marketers to carry out targeted active actions on content, classifying them regularly into groups of similar estimated risk of outflow [10]. S. Opoku Oppong, D. Asamoah, E. Ofor Oppong, D. Lamptey 
point out that decisions are vital for organizational development, consumer views and feedback are equally important for decision making. therefore, it is necessary to study their tastes, moods, emotions and embody them in the product [11].

The third component of managing the economic security of the organization is the use of modern management tools. J. Surasma Surung, I.P. Agung Bayupati, G. Agung Ayu Putri note the effectiveness of implementing a system with the concept of ERP in the organization is a form of effective strategy for efficiency and improving organizational efficiency [12].

Any processes in the organization are business. Business processes are a logically constructed sequence of actions that should lead from the entrance to the process to the exit, ie to obtain a result $[13$, p. 92].

B. Joseph Pine II, James X. Gilmore rightly point out that investors are not interested in the business that becomes a client, unless he is interested in reducing the degree of risk in their activities [14].

The fourth component of the management of economic security of the organization is information support. O. Pursky, D. Mazoha emphasize the importance of implementing an architectural model of an integrated web-based e-commerce business process management system [15].

The fifth feature of effective management of economic security of the organization is the control of logistics business processes. Because logistics is a business-oriented process, so Z. Benotmane, Gh. Belalem, A. Neki offer in their work a system of measuring decision support to estimate the costs associated with each logistics process. This system allows you to calculate the economic, environmental and social costs of the logistics process to ensure sustainable logistics [16]. In logistics management, Anitha P., Malini M. Patil emphasize that it is worth analyzing the availability of stocks to make forecasts, which are in the form of reports, queries and forecasts. Due to price, weather patterns, economic instability and the complexity of the nature of the business, forecasts may be inaccurate [17].

The analysis of Y.O. Yarova, L.P. Artemenko on studying the structure of economic risk management shows that to achieve a high level of economic security the company must ensure the structural balance of the main functional components: financial, intellectual, personnel, social, technical, technological, legal, informational, environmental, power, energy, innovation. Reliable economic security of the enterprise is possible only with a comprehensive and systematic approach, which allows to ensure the strategic development of the enterprise, to develop tactical and operational actions to minimize the effects of the crisis and the negative impact of threats [18].

Based on the study, we can conclude that in the management of economic security of the organization it is recommended to use a system-structural approach, which allows a comprehensive approach to the analysis of economic risk and the choice of control and regulatory actions.

\section{Discussion of results.}

The practical application of the author's model of economic security management of the organization on the basis of a system-structural approach involves the assessment of managers of the economic results of anticrisis measures. The effectiveness of the management model of economic security of the organization on the basis of system-structural approach can be assessed using the following formulas (1.1) and (1.2):

$$
R=P \times A(1.1),
$$

where, $\mathrm{P}$ - the probability of danger (from internal or external environments);

A - the expected amount of damage (losses to the organization);

$$
\left(\frac{\text { Eyp }}{(3 \kappa+3 \Pi+3 p+3 ч)}\right)-R(1.2)
$$

where, Pyp - the end result of risk management (economic efficiency);

$\mathrm{Zk}$ - the cost of money for anti-crisis measures;

$\mathrm{Zp}$ - labor costs of managers and staff to implement anti-crisis measures, actions;

3ч - the cost of material resources required for the implementation of anti-crisis measures;

Mf - the time required to implement all anti-crisis measures.

According to formula 1.2, managers get two possible results:

If $P y p \geq 0$, measures to counteract economic risks gave a positive result and the problem was eliminated;

If $P y p \mathrm{r}<0$, measures to counter economic risks have proved ineffective, the problem is not solved) it is necessary to look for an alternative management solution;

Therefore, this mathematical apparatus allows to take into account the probability of the problem, the costs incurred and the effectiveness of risk management. With its help, the acceptance of managerial risks by managers of the organization will be more balanced and economically sound, which will allow you to choose the best solution and assess its possible outcome (consequences). We conducted a survey among 16 managers of leading companies in the 
city of Kropyvnytskyi (ATB-market, Comfy, supermarket Furshet), which confirmed the positive result from the implementation of these proposals.

The results of the experiment on the implementation of the model of economic security management of the organization on the basis of system-structural approach are shown in Table 1.

Table 1. The results of the experiment on the implementation of the model of economic security management of the organization on the basis

\begin{tabular}{|c|c|c|c|c|}
\hline \multirow[t]{2}{*}{$\begin{array}{l}\text { Organizations } \\
\text { are objects of } \\
\text { economic risk } \\
\text { research }\end{array}$} & $\begin{array}{l}\text { Number of } \\
\text { management } \\
\text { decisions that } \\
\text { turned out to } \\
\text { be wrong (for } \\
1 \text { month) }\end{array}$ & $\begin{array}{l}\text { Number of } \\
\text { management } \\
\text { decisions that } \\
\text { turned out to } \\
\text { be correct (for } \\
1 \text { month) }\end{array}$ & \multirow[t]{2}{*}{$R$} & \multirow[t]{2}{*}{ Pyp } \\
\hline & $\begin{array}{l}\text { Before } \\
\text { the } \\
\text { introduction } \\
\text { of the model }\end{array}$ & $\begin{array}{l}\text { After the } \\
\text { introduction } \\
\text { of the model }\end{array}$ & & \\
\hline АТБ- market & 11 & $7(-4)$ & 1,2 & 4,7 \\
\hline Comfy & 9 & $4(-5)$ & 0,9 & 7,8 \\
\hline $\begin{array}{l}\text { Supermarket } \\
\text { Furschet }\end{array}$ & 13 & $8(-5)$ & 1,6 & 3,9 \\
\hline
\end{tabular}

The results of the experiment before and after the implementation of the model of economic security management of the organization at trade organizations in Kropyvnytskyi (Ukraine)

Thus, after the experiment (in October 2020) the number of incorrect decisions made by managers to eliminate economic risks (in the field of personnel management, production and logistics) decreased (-4; 5 ; -5 ), Ruhr indicators $\geq 0$. Countermeasures economic risks gave a positive result and the problem was eliminated, which indicates the successful implementation of the proposed model.

Therefore, measures to improve the economic risks of the organization should be focused on the optimal use of its own assets, personnel, funds, resources and time.

\section{CONCLUSIONS}

It is determined that risk management is the concept of doing business by an organization, which involves the creation of effective actions, methods, procedures and mechanisms to identify and eliminate (or reduce) the effects of economic risks that harm the organization to stabilize its business and market strategy. .

The essence of the system-structural approach is substantiated, according to which any organization should be considered as an open social and production system, which consists of appropriate levels of management, elements and connections between them, as well as the purpose of economic activity and appropriate management mechanisms.

System-structural approach is based on three postulates that: the organization should be considered as a system; the organization should be considered by levels of management, the availability of management technology, vertical and horizontal coordination of work.

The author's model of economic security management of the organization on the basis of systemstructural approach is constructed and its elements are characterized: the program of anti-crisis management, methods of risk management, means of control.

The requirements to the management of economic security of the organization on the basis of systemstructural approach are described: orientation on personnel, interaction with consumers, use of modern tools of management of business processes, information maintenance, control of logistic business processes of the organization.

\section{REFERENCES}

[1] Orlyk, O.V. (2017), "Classification and systematization of threats to financial and economic security of enterprises", Visnyk sotsialno-ekonomichnykh doslidzhen, № 1, pp. 106-115.

[2] Dovhan, V.V. (2002), Opit predprynymatelia [Entrepreneur experience], Moscow, Russia, $365 \mathrm{p}$.

[3] Kerekesha, O. Misko, H. and Maliuta, O. (2015), "The essence and role of economic security of the enterprise”, Ekonomichnyi dyskurs, № 4, pp. 3744.

[4] Shumilo, O.S. (2015), "Factors and threats to the economic security of commercial enterprises", Biznes Inform, №11, pp. 240-245.

[5] Adonin, S.V. and Kalashnikova, Yu.M. (2019), "Problems of economic security assessment of a modern enterprise", Ekonomichnyi prostir, № 148 , pp. 106-115.

[6] Chekulaev, M. (2002), Risk-menedzhment: upravlenie finansovyimi riskami na osnove analiza volatilnosti [Risk management: financial risk management based on volatility analysis], Alpina Pablisher, Moscow, Russia, 344 p.

[7] Denysenko, M.P. and Kolisnichenko, P.T. (2017), "Priority areas for strengthening economic security", Ekonomika ta derzhava, №3, pp. 31-35. 
[8] Shneyder, A. Katsman, Ya. and Topchishvili, G. (2001), Nauka pobezhdat $v$ investitsiyah, menedzhmente $i$ marketing [The science of winning in investment, management and marketing], AST, Moscow, Russia, 240 p.

[9] Demarko, T. Lister, T. (2008), Chelovecheskiy faktor: uspeshnyie proektyi $i$ komandyi [The human factor: successful projects and teams], Simvol-Plyus, St. Petersburg, Russia, 256 p.

[10] Deligiannis, A. Argyriou, C. (2020), “Designing a Real-Time Data-Driven Customer Churn Risk Indicator for Subscription Commerce", International Journal of Information Engineering and Electronic Business, vol. 12. № 4, pp. 1-14.

[11] Opoku Oppong, S. Asamoah, D. Ofori Oppong E. and Lamptey, D. (2019), "Business Decision Support System based on Sentiment Analysis". International Journal of Information Engineering and Electronic Business, vol. 11, № 1, pp. 36-49.

[12] Surasma Surung J., Agung Bayupati, I.P. Agung Ayu Putri G. (2020), "The Implementation Of ERP In Supply Chain Management On Conventional Woven Fabric Business", International Journal of Information Engineering and Electronic Business (IJIEEB). vol. 12, № 3, pp. 8-18.

[13] Fydelman, H.N. Dedykov, S.V. and Adler, Yu.P.. Alternatyvnii menedzhment: put $k$ hlobalnoi konkurentosposobnosty [Alternative management: the path to global competitiveness], Alpina Biznes Buks, Moscow, Russia, 186 p.

[14] D. Payn II and D. Gilmor (2011), Ekonomika vpechatleniy [The economy of impressions], Alpina Pablisherz, Moscow, Russia, 330 p.

[15] Pursky, O. and Mazoha, D. (2018), “Architecture Model of Integrated Web-based E-trading Business Process Management System", International Journal of Information Engineering and Electronic Business, vol. 10, № 2, pp. 1-8.

[16] Benotmane, Z. Belalem, Gh. and Neki, A. (2018), "A Cost Measurement System of Logistics Process", International Journal of Information Engineering and Electronic Business, vol. 10, № 5, pp. 23-29.

[17] Anitha, P. and Malini, M. Patil (2018), “A Review on Data Analytics for Supply Chain Management: A Case study", International Journal of Information Engineering and Electronic Business, vol. 10, № 5, pp. 30-39.

[18] Yarova, Yu.O. and Artemenko, L.P. (2016), “The structure of economic security of the enterprise in a crisis", Ekonomichnyi visnyk Natsionalnoho tekhnichnoho universytetu Ukrainy "Kyivskyi politekhnichnyi instytut". № 13. pp. 257-263. available. 